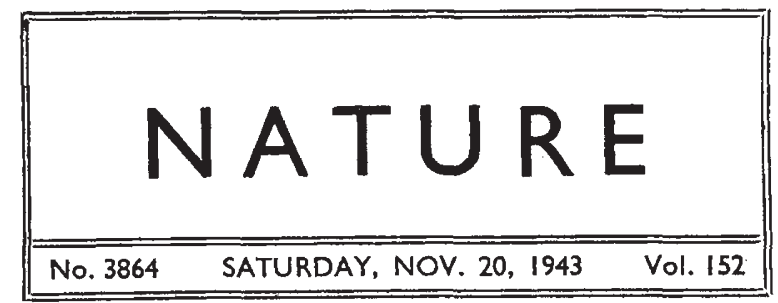

CONTENTS

Industry, Research and Education in Great Britain . 579

Sex Education and Guidance . . . . 582

Recent Advances in Virus Research. Ey Prof. Wilson Smith

Meteorology as a Cultural Subject. By Prof. D. Brunt Mouse Genetics. By Dr. C. H. Waddington . .

Keeping up with Organic Chemistry. By Prof. John Read, F.R.S.

The Future of Anthropology . . . . . 587

Geography and International Settlement. By W.

Fitzgerald . . . . . . . .

Spatial Isolation of Seed Crops. By Gordon Haskell . 591

Obituaries :

Prof. W. M. Tattersall. By Dr. Stanley Kemp, F.R.S.

Mr. J. J. A. Jones .

News and Views.

Letters to the Editors:

J. B. Hannay and the Artificial Production of Diamonds.-The Rt. Hon. Lord Rayleigh, F.R.S.

Single-Fibre Response from an Intact Animal.-Dr. W. A. H. Rushton and H. B. Barlow

Osmotic Regulation in Sabella pavonina.-Dr. D. W. Ewer and R. F. Ewer

Siderocytes in Mammalian Blood.-Robert A. M. Case

Fragility of Erythrocytes in Hypotonic Saline.A. C. Roy

Determination of Ascorbic Acid in the Presence of Sulphur Dioxide.-Dr. L. F. Levy . .

Constitution of Calycanine.-Dr. A. Hargreaves

Non-Solar Planetary Systems.-H. K. Sen .

Propagation of Potatoes.-Dr. Nicholas Polunin .

International Languages.-E. T. Harris

James Prescott Joule and the Unit of Energy.-

Dr. K. R. Webb ; Prof. C. H. Lees, F.R.S. ;

Prof. W. Peddie. . . . . .

"Timbers of the New World".-Prof. Samuel J. Record

The New Algebras

N. Department of Scientific Research

Researches on Penicillin . . . . . . 604

Wood Utilization . . . . . . . 605

Physiological Basis of Camouflage . . . . 605

Editorial and Publishing Offices

MACMILLAN \& CO., LTD.,

ST. MARTIN'S STREET, LONDON, W.C.2.

Telephone Number: Whitehall 8831

Telegrams : Phusis Lesquare London Advertisements should be oddressed to

T. G. Scott \& Son, Ltd., Talbot House, 9 Arundel Street, London, W.C.2 Telephone: Temple Bar 1942

The annua I subscription rate is $\leqslant 4100$, payable in advance, Inland or Abroad. All rights reserved. Registered as a Newspaper at the General Post Office

\section{INDUSTRY, RESEARCH AND EDUCATION IN GREAT BRITAIN}

T $T$ was one of the merits of the annual reports 1 of the Department of Scientific and Industrial Research that they afforded something of the nature of an annual stocktaking of the research effort of Great Britain. The broad surveys which appeared over the signature of successive chairmen of the the Advisory Council, such as Lord Rutherford and Lord Riverdale, rarely failed to point not merely to achievements but also to directions in which further efforts were required. Although the War has interrupted this fruitful and effective method of encour. aging research-mindedness, noteworthy efforts at education have been made in this field during recent months. Debates on economic policy demonstrated a widespread realization in the House of Commons that adequate research must be the foundation of an expanding export trade. Dr. P. Dunsheath's lecture to the Royal Society of Arts on "Industrial Research in Great Britain : A Policy for the Future" is only one of a number of occasions when the whole structure and policy of industrial research has come under review.

Two of the most notable have been the debate on scientific research in the House of Lords on July 15 and 20 and a memorandum on the meaning of research for industry prepared by Sir Harold Hartley. Sir Harold Hartley affirms his belief that industrial research will be the vital factor in determining the future prosperity of Great Britain, and his paper is a plea to industry to accept the help which science can give, and for more industrialists to become research-minded. Despite some outstanding exceptions, there has not been in Great Britain a general appreciation of the value of science in industry, and the expenditure on research has been correspondingly less than in Germany or the United States of America. While British men of science have proved in both the world wars that they can more than hold their own if they are given equal facilities and support, it is impossible to avoid the conclusion that if Great Britain is to maintain its position in the world markets, industry must give greatly increased attention to research as soon as the progress of the War makes it possible. Industrialists should be taking active steps now to organize this aspect of their post-war activities.

This same point is well made in an article on "Foundations of Prosperity" in the Round Table. On the technical side, it is pointed out, the failures: of industry have come mainly from inadequate support of scientific research and from unwillingness or inability to scrap obsolete plant. That is one reason for the concern which has been expressed regarding recent pronouncements as to the post-war policy of the British motor-car industry; these statements have aroused doubts as to whether the policy is sufficiently bold and forward-looking and not too tied to pre-war ideas, and reluctant to replace out-of-date plant. As a nation we still present a curious contrast between the most outstanding 
individual achievement in every branch of science, and a certain suspicion and scepticism concerning the practical value of the scientific approach to industrial problems. There are still managements and workers in the iron and steel and engineering industries whose belief in traditional practices constantly obstructs the use of metallurgical or physical knowledge. Lord Listowel has solid ground for his assertion that full employment and better conditions of life after the War largely depend on our capacity to modernize industrial equipment and processes and to improve the quality and quantity of their output, checking the failure to keep abreast of the times which has characterized some fields of industry.

On this question of obsolescence the Round Table article makes the important suggestion that while neither Government nor industry alone can provide a remedy for such technical deficiencies, the Government contribution should not only include raising the standard of education and the promotion of scientific research, in national institutions and in the universities as well as by industrial concerns, but also by devising a system of taxation which will encourage instead of penalize the modernization of equipment. There is no more urgent task in administration than the reform of the principles of inland revenue. Taxation has come to be looked on departmentally as an end in itself, and until that notion is killed and the corpus of statutes and interpretations built up around the income tax over a century, and more is swept away and replaced by principles more in accord with the facts and requirements of modern life, it will remain true that the industries most in need of modernization are those least able to afford it.

Sir Harold Hartley's memorandum is strangely silent on this important point; but, almost simultaneously with the Round Table article, the Economist, in its centenary number, lends powerful support from another outlook to this plea for reconsideration of taxation policy in regard to obsolescence and development. But all three agree on the importance of the obligation of enterprise in industry, and the words of the Round Table article might appear equally well in either of the others : "No Board of Directors in these coming years of stress and reconstruction will be acting in consonance with the spirit and needs of the age, or indeed with the interests of its shareholders, unless it puts back into the business a substantial part of the profits to cover research, development and obsolescence. No organized industry can hope to survive in a world market if it falls behind in these matters or is deluded by the Inland Revenue into the belief that advertisement is more than all these things". The same point was well made by Lord Listowel in the House of Lords in urging a steady increase in existing facilities for scientific research into the post-war problems of industry.

That is Sir Harold Hartley's argument, and his review of the present organization of research in Great Britain leads him to make several concrete suggestions. Even the smallest firm should find a place on its staff for at least one man with a scientific training, and should join the research association for its trade. If there is no research association, the trade associa- tion should be urged to approach the Department of Scientific and Industrial Research with the view of forming a research association. If the trade has no trade association and no research association, firms which do not employ a research staff are recom. mended to apply to the Federation of British Indus. tries for advice. If they are in a large way of business they are also advised to consider the establishment, alone or with associated or kindred firms, of a research laboratory. Closer contact between scientific men in industry and those in the universities, and more integration between research and development are also suggested, but Sir Harold does not mention three points which were repeatedly stressed in the House of Lords : adequate remuneration of scientific workers in industry; undue reluctance to pool information on new developments; and the lack of appreci. ation of scientific methods by the higher Civil Service.

It will be noted that Sir Harold Hartley appears to place his main emphasis on the research association, but it may well be doubted whether, except with the smallest firms, this is anything like the most effective line of advance. On this point Lord McGowan spoke explicitly in the House of Lords debate. While recog. nizing the value of a research association where no single unit is in a position to create a research installa. tion on a suitable scale, and paying tribute to the work of the Department of Scientific and Industrial Resoarch in fostering and encouraging the research associations, he thought that this system of research, while it may play a large part in future development, has a very long way to go before we can be satisfied that it is up to the standard demanded by modern conditions.

The reasons for this position are readily seen. It can be maintained with considerable force of argu. ment that the true field of work of the research associations lies in the fundamental investigations on the basic problems of the industry-investigations which require planning and co-ordinating frequently in relation to the scientific research which is pro. ceeding at the universities and independent research institutes. There are practical reasons why the research association can never hope to compete effectively with the research department of an in. dividual firm or group of associated firms in the investigation of day-to-day problems and existing processes, in the search for higher efficiency, lower costs and new and improved products. Yet it is exactly on such problems that some research asso. ciations tend to concentrate.

This indeed is only what might be expected. An association of firms which individually are not research-minded enough to establish their own research departments, in spite of ample resources, are unlikely to take the long-range view and support the attack by the research association of the fundamental problems on which eventually the prosperity or even the existence of the industry may depend. Lord Cherwell's statement showed that the Govern. ment is aware of the importance of fundamental research and prepared to extend its support, but the mere formation of a research association is only the 
first step in a programme of education and inculcating research-mindedness. It may well be maintained that the whole experience of the research association movement would endorse the plea for an investigation of taxation methods in relation to research and development for which the Round Table and the Economist have so boldly called.

We touch here on questions of industrial structure as well as of the organization of research. In reconsidering the structure of industry, this question of research is of cardinal importance in ensuring that spirit and policy of enterprise which are essential both in private industry and in any form of public corporation which may be established to provide safeguards for the public interest. Unless that spirit pervades the management, no change in organization or structure will avert disaster or provide the developments and technical advances on which a policy of full employment and rising standards of living can be firmly based.

Sir Harold Hartley's memorandum may well prove a timely corrective in some of the discussions at present proceeding in these fields, and it is the more encouraging to find that many of his points have been made very forcefully in the House of Lords debate already mentioned. The emphasis which Lord Samuel, Lord McGowan and Lord Dawson of Penn laid on the importance of the highest administrative positions in government service being open to technical and scientific men who had shown themselves fit for such work is indeed relevant. Without support from the top we cannot expect that the resources of research associations or of universities will be adequate for the tasks which now confront them.

What is most welcome in the attention now being concentrated on industrial research is the recognition that this is a matter in which both industry and Government have responsibilities. In addition to the responsibility in regard to the Civil Service and administration just mentioned, the Government must carry a prime responsibility in regard to the adequate endowment of scientific research at the universities. Commenting on Sir Harold Hartley's proposals, Sir Ernest Simon has stated that preliminary investigations of a committee of scientific men and industrialists set up by the University of Manchester to consider what developments are needed to enable the Univer. sity to render services to industry equivalent to those rendered by leading universities in America, indicate that it will be necessary to think in terms of trebling the Government grant to universities.

Whether or not, as Mr. Bruce Truscot has suggested in his recent book, the universities of Great Britain might make a larger contribution to research from their existing resources, a much larger State endowment is clearly imperative. Lord McGowan has indicated, however, that here also industry has a big part to play. There can now be little doubt that those who insisted that it should be a condition of protection under the Import Duties Act that the industries concerned should pursue an active policy of research and development were fundamentally right. Failure to insist on this, for example, in the iron and steel industry, has clearly been unfortunate, and the record of the Import Duties Advisory Com. mittee is largely one of missed opportunities from which the whole country has suffered.

Lord McGowan made the point effectively in urging this as one reason why industry should play its part in encouraging scientific developments in the universities and technical schools of Britain. He pleaded for industry to play its part by means of financial grants, particularly to ensure that equipment is adequate in quality and in amount.

But this question of closer contact between the industrial and the academic worlds to which Lord McGowan referred touches closely the question of education. Mutual discussion between industry and the academic man of science may be largely profitless if the standard of education in industry is not suffi. ciently high. The extension of scientific academic facilities and of technical schools is a post-war issue of the utmost importance if Britain is to hold her own and realize the possibilities which greater research-mindedness on the part of industry might put within her reach. Lord Maugham commented trenchantly on the absence of reference to science in the White Paper on Education, and there are few signs that the opportunity which is offered to us by the scientific developments in the Fighting Services and the consequent wider interest in technical science are fully comprehended.

Education, indeed, in its broadest sense, is the key to the situation. The education of the industrialist, for which Sir Harold Hartley pleads, is one line of advance. The education of the Civil servant and the opening of the higher posts in the Civil Service to those trained in scientific research is another, and on this point Lord Cherwell's statement for the Government was hopeful. The extension and improvement of university facilities and of those for technical training at all levels is another, and it is clear from recent statements that have been made that this aspect is being borne in mind. Vital as it may be to effect immediate improvements by all these means, to secure a fuller endowment of research and development work, its adequate co-ordination by administrators imaginatively alive to the issues involved-and that at every stage in industry, from management to the operative-and a personnel technically and scientifically competent, ultimately it is on the elucational system of Great Britain that sustained progress depends. To fulfil the manifold requirements, the system must provide the State and industry alike at all levels with recruits equipped to face the tasks of the new age and aware of the scieritific and technical factors which enter into its social, industrial, economic and international prob. lems, as well as of the human, moral and cultural values. It is only in this way that industry and State can be directed and staffed by those aware of the vast possibilities of research, competent to plan and to execute an adequate policy of research, and resolute to see that it issues both in greater efficiency in industry and also in the wider and fuller enjoyment by society of the resources which science has put at our command. 